\title{
EFEKTIVITAS PERSONAL SELLING PADA PT. WISUNDHA NETWORK GLOBALINDO TABANAN
}

\author{
I Nyoman Teguh Purbawa ${ }^{1}$, I Nyoman Sujana ${ }^{2}$, Anjuman Zukhri ${ }^{3}$ \\ Jurusan Pendidikan Ekonomi \\ Unversitas Pendidikan Ganesha \\ Singaraja, Indonesia \\ e-mail :teguhpurbawa@gmail.com,sujanatbn@yahoo.com, \\ anjuman.zukhri@undiksha.ac.id
}

\begin{abstract}
Abstrak
Penelitian ini bertujuan untuk mengetahui efektivitas personal selling pada PT. Wisundha Network Globalindo Tabanan. Jenis penelitian ini adalah penelitian deskriptif dengan pendekatan kualitatif. Subjek dalam penelitian ini adalah karyawan yang memberikan informasi mengenai efektivitas personal selling pada PT. Wisundha Network Globalindo Tabanan. Objek dalam penelitian ini adalah efektivitas personal selling pada PT. Wisundha Network Globalindo Tabanan. Analisis data menggunakan ukuran efektivitas dengan kriteria keefektivan sangat efektif, efektif, cukup efektif, tidak efektif, dan sangat tidak efektif. Hasil penelitian menunjukkan bahwa PT. Wisundha Network Globalindo Tabanan belum dapat mencapai target yang telah ditetapkan, namun demikian hasil perhitungan efektivitas $81,2 \%$ sangat efektif. Analisis efektivitas personal selling perbulan selama satu tahun, menunjukan pada bulan Januari, Februari, Maret, April, dan Mei penjualan sudah efektif dan pada bulan Juni, Juli, Agustus, September, Oktober, November, dan Desember penjualan sangat efektif.
\end{abstract}

Kata Kunci : Efektivitas Personal Selling

\begin{abstract}
This study aims to determine the effectiveness of personal selling at PT. Wisundha Network Globalindo Tabanan. The type of this research is descriptive research with qualitative approach. Subjects in this study are employees who provide information about the effectiveness of personal selling at PT. Wisundha Network Globalindo Tabanan. The object of this research is the effectiveness of personal selling at PT. Wisundha Network Globalindo Tabanan. The analysis of data using measures of effectiveness with effectiveness criteria is very effective, effective, effective enough, ineffective, and highly ineffective. The results showed that PT. Wisundha Network Globalindo Tabanan has not been able to achieve the set targets, but the results of $81.2 \%$ effectiveness calculations are very effective. Analysis of monthly personal selling effectiveness during one year shows that in January, February, March, April, and May sales are effective and in June, July, August, September, October, November, and December sales are very effective.
\end{abstract}

\section{PENDAHULUAN}

Keywords: The Effectiveness Of Personal Selling

Dalam dunia usaha sekarang ini tingkat persaingan antara industri-industri bisnis semakin tajam, tak terkecuali dengan perusahaan-perusahaan yang berada di Indonesia. Dengan semakin majunya teknologi pada era globalisasi ini, setiap perusahaan berusaha untuk selalu meningkatkan kualitas produksi maupun manajemen pemasaran dengan tujuan memaksimalkan keuntungankeuntungan sesuai target yang diinginkan oleh setiap perusahaan. Persaingan yang semakin ketat dalam dunia bisnis telah merambah ke semua sektor usaha (bisnis), sehingga kompetisi yang ada antara perusahaan 
semakin ketat. Suatu perusahaan dituntut untuk mampu menghadapi berbagai kendala yang timbul dalam mengelola bisnis usaha pemasarannya, juga untuk menjamin perusahaan yang bersangkutan supaya dapat beroperasi dengan manajemen yang efektif dan efisien. Kegiatan pemasaran sudah diketahui semenjak manusia mulai mengenal sistem pembagian kerja dalam masyarakat, sehingga kelompok masyarakat hanya membuat suatu barang dan melakukan kegiatan barter (tukar-menukar) hanya saja kegiatan pemasaran itu masih dalam bentuk sederhana.

$$
\text { Kegiatan pemasaran sudah }
$$

diketahui semenjak manusia mulai mengenal sistem pembagian kerja dalam masyarakat, sehingga kelompok masyarakat hanya membuat suatu barang dan melakukan kegiatan barter (tukarmenukar) hanya saja kegiatan pemasaran itu masih dalam bentuk sederhana.

$$
\text { Menurut Swastha (2000:5) }
$$

pemasaran adalah suatu keseluruhan dari kegiatan usaha yang ditujukan untuk merencanakan, menentukan harga, mempromosikan, dan mendistribusikan barang dan jasa yang dapat memuaskan kebutuhan baik kepada pembeli yang ada maupun pembeli potensial. Definisi lainnya, menurut Hasan (2008:1) pemasaran merupakan konsep ilmu dalam strategi bisnis yang bertujuan untuk mencapai keputusan berkelanjutan bagi stakeholder (pelanggan, karyawan, pemegang saham). Sebuah perusahaan baik itu perushaan jasa maupun industri lainnya akan menggunakan berbagai strategi dalam memasarkan produknya, hal ini dikarenakan kondisi persaingan saat ini yang sangat ketat, jika sebuah perusahaan tidak menggunakan strategi yang tepat, maka perusahaan akan kalah dalam persaingan merebut pangsa pasar.

Dari definisi di atas, dapat disimpulkan bahwa pemasaran merupakan suatu proses panjang yang dilakukan oleh perusahaan untuk menjalankan roda bisnisnya. Proses pemasaran meliputi menentukan produk, menentukan pasar, menghitung harga, dan melakukan promosi, sehingga proses pemasaran terjadi atau dimulai sebelum produk itu ada.
Perusahaan harus dapat memberikan kepuasan kepada konsumen sehingga konsumen mempunyai pandangan yang positif kepada perusahaan. Pengenalan produk kepada konsumen merupakan kegiatan yang harus dilakukan agar suatu produk diperoleh pasar. Kegiatan tersebut dilakukan dikarenakan agar produk tersebut dapat diterima oleh konsumen, dan seharusnya perusahaan merencanakan terlebih dahulu bagaimana marketing yang harus dilakukan, sehingga produk dapat diciptakan sesuai dengan kebutuhan dan keinginan pasar.

Pengusaha yang sudah mulai mengenal bahwa pemasaran merupakan faktor penting untuk mencapai sukses bagi perusahaanya, akan mengetahui adanya cara dan falsafah baru yang disebut konsep pemasaran. Menurut Kotler (2012:17) konsep pemasaran yaitu konsep pemasaran menyatakan bahwa kunci untuk meraih tujuan organisasi adalah menjadi efektif daripada pesaing dalam memadukan kegiatan pemasaran guna menetapkan dan memuaskan kebutuhan dan keinginan pasar sasaran. Perusahaan melalui konsep pemasaran akan berhasil bilamana berpijak pada tiga faktor dasar yang meliputi seluruh perencanaan dan kegiatan perusahaan haruslah berorientasi pada konsumen atau pasar. Volume penjualan yang menguntungkan dapat dicapai, melalui pemuasan kebutuhan konsumen. Seluruh kegiatan pemasaran haruslah dikoordinasikan dan diintegrasikan, agar dapat memberikan kepuasan optimal kepada konsumen.

Konsep pemasaran tersebut dibuat dengan menggunakan 3 faktor dasar seperti yang terdapat dibawah ini yang dikemukakan oleh Swastha (2005:8) Orientasi pada konsumen pada pokoknya, perusahaan yang ingin mempraktekkan orientasi konsumen ini harus menentukan kebutuhan pokok dari pembeli yang akan dilayani dan dipenuhi.memilih kelompok pembeli tertentu sebagai sasaran dalam penjualannya, menentukan produk dan program pemasaran., mengadakan penelitian pada konsumen untuk mengukur, menilai dan mentafsirkan keinginan, sikap, serta tingkah laku mereka, dan menentukan dan melaksanakan strategi yang paling baik 
apakah menitikberatkan pada mutu yang tinggi, harga yang murah atau merk yang menarik.

Koordinasi dan integrasi dalam perusahaan maksudnya sikap orang dan setiap bagian dalam perusahaan memberikan kepuasan konsumen, sehingga tujuan perusahaan dapat direalisir dan mendapatkan laba melalui pemuasan konsumen tujuan menggunakan konsep pemasaran ini adalah untuk memperbaiki hubungan konsumen karena hubungan yang lebih baik sangat menguntungkan bagi perusahaan dan dapat meningkatkan laba.

Pengertian pemasaran menurut Swastha (2008:5) adalah pemasaran adalah suatu sistem keseluruhan dari kegiatan-kegiatan bisnis yang ditujukan untuk merencanakan, menentukan harga, mempromosikan, dan mendistribusikan barang dan jasa yang memuaskan kebutuhan baik kepada pembeli yang ada maupun pembeli potensial. Strategi Pemasaran menurut Assauri (2013:15) Strategi pemasaran adalah serangkaian tujuan dan sasaran, kebijakan dan aturan yang memberi arah kepada usaha-usaha pemasaran perusahaan dari waktu ke waktu, pada masingmasing tingkatan dan acuan serta alokasinya, terutama sebagai tanggapan perusahaan dalam menghadapi lingkungan dan keadaan persaingan yang selalu berubah. Menurut Swastha (2008:61) Setiap perusahaan menjalankan strategi pemasaran untuk mencapai tujuan yang diharapkan. Ada tiga tahap yang ditempuh perusahaan untuk menetapkan strategi pemasaran adalah memilih konsumen yang dituju, mengidentifikasi keinginan konsumen, dan menentukan bauran pemasaran.

Konsep pemasaran bertujuan memberikan kepuasan terhadap keinginan dan kebutuhan konsumen, atau berorientasi pada konsumen. Konsep pemasaran mengajarkan bahwa kegiatan pemasaran suatu perusahaan harus dimulai dengan usaha mengenal dan merumuskan keinsinan dan kebutuhan danri konsumennya. Kemudian perusahaan itu harus merumuskan dan menyusun suatu kombinasi dari kebijaksanaan produk, harga dan distribusi setepat-tepatnya agar kebutuhan para konsumennya dapat dipenuhi secara memuaskan.

Strategi pemasaran berfokus pada tujuan jangka panjang perusahaan dan melibatkan perusahaan dan melibatkan perncanaan program-program pemasaran untuk mewujudkan tujuan perusahaan. Perusahaan bergantung pada strategi pemasaran untuk menerapkan produk atau jasanya, termasuk produk dan jasa baru. Menurut Hermawan (2012:40) strategi pemasaran adalah proses perencanaan dan implementasi kebijakan perusahaan untuk mewujudkan tujuan-tujuan perusahaan yang sesuai dengan visi perusahaan. Persaingan merupakan sebuah motivasi utama dalam strategi pemsaran. Strategi pemasran sangatlah penting bagi perusahaan untuk terus mencapai keuntungan dalam setiap industri.

Strategi pemasaran yang baik harus dibangun atas dasar pemahaman bisnis yang kuat dalam dinamika pasar, dikombinasikan dengan pemahaman kebutuhan (needs) dan keinginan (wants), pesaing, skill human capital, pemasok baik kedalam maupun keluar. Tidak hanya itu, tetapi kemampuan untuk mempariasi "marketing mix, segmentation targeting dan positioning akan sangat membantu memenangkan persaingan bisnis".

Menurut Abdul (2016:89) strategi pemasaran adalah penetapan suatu rencana untuk mencapai tujuan dan sasaran yang diinginkan. Didalam pemasaran, yang diibaratkan sebagai medan tempur bagi para produsen, dan para pedagang, maka perlu sekali ditetapkan strategi bagaimana memenangkan peperangan. Banyak lawan dihadapi dalam medan pasar, namun lawan-lawan dalam medan pasar ini, tidak boleh dimatikan sebagaimana halnya musuh dalam perang militer. Terutama dalam sistem ekonomi pancasila diharuskan adanya saling asuh antara pengusaha kuat dan pengusaha lemah, sistem bapak angkat. Hanya dalam penguasaan pasar masing-masing mencoba menguasai pasar dan memperkokoh kedudukannya.

Menutur Hasan, (2008:41) bauran pemasaran adalah kombinasi kegiatan 
terkendali yang dikenal luas: produk, harga, distribusi, dan promosi yang harus dikelola untuk memenuhi kebutuhan dan keinginan konsumen, yang tercapainya kepuasaan pelanggan dan tujuan organisasi.

\begin{tabular}{llr}
\multicolumn{1}{c}{ Menurut } & Alma $(2012: 205)$, & bauran \\
pemasaran & merupakan & strategi \\
mencampuri & kegiatan & kegiatan \\
pemasaran, & agar dicari & kombinasi
\end{tabular}
maksimal sehingga mendatangkan hasil yang memuaskan. Marketing mix terdiri atas empat komponen atau disebut 4P yaitu product, price, place, promotion. Adapun pengertian 7P menurut Kotler \& Amstrong (2012:62) adalah yang pertama Product (Produk) adalah mengelola unsur produk termasuk perencanaan dan pengembangan produk atau jasa yang tepat untuk dipasarkan dengan mengubah produk atau jasa yang ada dengan menambah dan mengambil tindakan yang lain yang mempengaruhi bermacammacam produk atau jasa, yang kedua Price (Harga) adalah suatu sistem manajemen perusahaan yang akan menentukan harga dasar yang tepat bagi produk atau jasa dan harus menentukan strategi yang menyangkut potongan harga, pembayaran ongkos angkut dan berbagi variabel yang bersangkutan, yang ketiga Place (Distribusi) yakni memilih dan mengelola saluran perdagangan yang dipakai untukmenyalurkan produk atau jasa dan juga untuk melayani pasar sasaran, serta mengembangkan sistem distribusi untuk pengiriman dan perniagaan produk secara fisik yang keempat Promotion (Promosi) adalah suatu unsur yang digunakan untuk memberitahukan dan membujuk pasar tentang produk atau jasa yang baru pada perusahaan melalui iklan, penjualan pribadi, promosi penjualan, maupun publikasi, yang kelima Physical Evidence (Sarana fisik) merupakan hal nyata yang turut mempengaruhi keputusan konsumen untuk membeli dan menggunakan produk atau jasa yang ditawarkan. Unsur yang termasuk dalam sarana fisik antara lain lingkungan atau bangunan fisik, peralatan, perlengkapan, logo, warna dan barangbarang lainnya, yang keenam People (Orangnyaa) adalah semua pelaku yang memainkan peranan penting dalam penyajian jasa sehingga dapat mempengaruhi persepsi pembeli. Elemen dari orang adalah pegawai perusahaan, konsumen, dan konsumen lain. Semua sikap dan tindakan karyawan, cara berpakaian karyawan dan penampilan karyawan memiliki pengaruh terhadap keberhasilan penyampaian jasa, dan yang ke tujuh Process (Proses) adalah semua prosedur aktual, mekanisme, dan aliran aktivitas yang digunakan untuk menyampaikan jasa. Elemen proses ini memiliki arti sesuatu untuk menyampaikan jasa. Proses dalam jasa merupakan faktor utama dalam bauran pemasaran jasa seperti pelanggan jasa akan senang merasakan sistem penyerahan jasa sebagai bagian jasa itu sendiri. Menurut Gitosudarmo, (2000:110) bauran pemasaran merupakan alat yang dapat dipergunakan oleh pengusaha untuk mempengaruhi konsumennya dengan melakukan tindakan-tindakan pada produk, harga, promosi dan distribusi

Promosi merupakan teknik komunikasi yang secara penggunaannya atau penyampaiannya dengan menggunakan media seperti: pers, televisi, radio, papan nama, poster dan lain-lain yang bertujuannya untuk menarik minat konsumen terhadap hasil produksi suatu perusahaan. Promosi sebagai media untuk menjembatani kepentingan produsen dengan konsumen. Menurut Hermawan (2012:128), "Promosi penjualan merupakan aktivitas pemasaran yang mengusulkan nilai tambah dari suatu produk dalam jangka waktu tertentu guna mendorong pembelian konsumen, efektivitas penjualan, atau mendorong upaya yang dilakukan oleh tenaga penjual". Dari uraian di atas maka dapat disimpulkan bahwa, promosi adalah tindakan yang dilakukan oleh perusahaan dengan jalan memengaruhi konsumen secara langsung ataupun tidak langsung untuk menciptaan pertukaran dalam pemasaran.

Jadi, jelas kiranya manajemen pemasaran tidak bisa terlepas dari berbagai macam faktor yang memengaruhi dalam menentukan kombinasi yang terbaik, guna memperoleh efektifitas dalam penggunaan dana, tenaga dan waktu dalam mencapai sukses pemasaran. Tujuan dari pada promosi adalah untuk 
memperkenalkan barang hasil produksi, dengan tujuan agar konsumen membeli hasil produksinya. Dengan demikian volume penjualan dapat meningkat, dan juga dapat meningkatkan laba perusahaan. Hal ini dapat dicapai oleh suatu perusahaan bila promosi yang dijalankan benar-benar tepat sehingga pelaksanaan promosi dapat berhasil seefektif mungkin.

Tujuan dari promosi merupakan suatu kebijakan perusahaan dalam kegiatan promosi, dimana tujuan dari promosi itu berbeda-beda menurut perusahaan apa yang dijalankannya, jadi suatu perusahaan dalam hal untuk melakukan suatu kegiatan promosi, memiliki beberapa tujuan. Dari kegiatan promosi tersebut antara lain untuk memberikan informasi, meningkatkan penjualan, serta nilai tambah dari suatu produk, agar produk yang dipasarkan bisa tetap terjual atau dibeli oleh konsumen walaupun pada masa tertentu yang berakibat pasar sasaran perusahaan mengalami penurunan penjualan.

Promosi sebagai alat untuk menyebarkan informasi memiliki beberapa komponen yang terdapat dalam bauran promosi. Bauran promosi menjadi pilihan komunikasi yang terdiri dari kombinasi promosi yang digunakan oleh perusahaan yang apabila mendapat tanggapan positif akan menguntungkan perusahaan. Menurut Kotler \& Armstrong (2012:432) mengemukakan bahwa bauran promosi (bauran komunikasi pemasaran) adalah campuran spesifik dari alat-alat promosi yang digunakan perusahaan untuk secara persuasif mengkomunikasikan nilai pelanggan dan membangun hubungan pelanggan. Menurut Kotler \& Armstrong (2012:432), bauran promosi terdiri atas 5 (lima) alat-alat promosi adalah yang pertama advertising (periklanan) yaitu semua bentuk presentasi dan promosi non personal yang dibayar oleh sponsor untuk mempresentasikan gagasan, barang atau jasa. Periklanan dianggap sebagai manajemen citra yang bertujuan menciptakan dan memelihara cipta dan makna dalam benak konsumen. Bentuk promosi yang digunakan mencakup broadcast, print, internet, outdoor, dan bentuk lainnya, yang kedua sales promotion (promosi penjualan) yaitu insentif-insentif jangka pendek untuk mendorong pembelian atau penjualan suatu produk atau jasa. Bentuk promosi yang digunakan mencakup discounts, coupons, displays, demonstrations, contests, sweepstakes, dan events, yang ketiga personal selling (penjualan perseorangan) yaitu presentasi personal oleh tenaga penjualan dengan tujuan menghasilkan penjualan dan membangun hubungan dengan konsumen. Bentuk promosi yang digunakan mencakup presentations, trade shows, dan incentive programs, yang keempat public relations (hubungan masyarakat) yaitu membangun hubungan yang baik dengan berbagai publik perusahaan supaya memperoleh publisitas yang menguntungkan, membangun citra perusahaan yang bagus, dan menangani atau meluruskan rumor, cerita, serta event yang tidak menguntungkan. Bentuk promosi yang digunakan mencakup press releases, sponsorships, special events, dan web pages, dan yang kelima direct marketing (penjualan langsung) yaitu hubungan langsung dengan sasaran konsumen dengan tujuan untuk memperoleh tanggapan segera dan membina hubungan yang abadi dengan konsumen. Bentuk promosi yang digunakan mencakup catalogs, telephone marketing, kiosks, internet, mobile marketing, dan lainnya

Menurut William G. Nickels, (dalam Hermawan, 2012:107). personal selling adalah interaksi antar individu, saling bertemu muka yang ditujukan untuk menciptakan, memperbaiki, menguasai dan mempertahankan hubungan pertukaran yang saling menguntungkan dengan pihak lain. Personal selling merupakan komunikasi langsung antara penjual dan calon pelanggan untuk memperkenalkan suatu produk dengan calon pelanggan dan membentuk suatu pemahaman pada suatu produk sehingga calon pelanggan akan mencoba dan membelinya.

Efektivitas berasal dari kata dasar efektif, menurut kamus besar Bahasa Indonesia efektiv adalah ada efeknya, manjur atau mujarab, dapat membawa hasil, berhasil guna dan mulai berlaku. Sementara itu efektivitas memiliki 
pengertian keefektivan adalah keadaan berpengaruh, kemanjuran, keberhasilan dan hal mulai berlaku. Menurut Keban (dalam Pasolong, 2010:4), mengatakan bahwa suatu organisasi dapat dikatakan efektif kalau tujuan organisasi atau nilainilai sebagaimana ditetapkan dalam visi tercapai. Sedangkan menurut Siagian (2002:151) adalah tercapainya suatu sasaran yang telah ditentukan pada waktunya dengan menggunakan sumbersumber data tertentu yang dialokasikan untuk menjalankan kegiatan-kegiantan organisasi tertentu.

Efektif lebih mengarah kepada pencapaian sasaran. Efesiensi dalam menggunakan masukan akan menghasilkan produktivitas yang tinggi, yang merupakan tujuan dar setiap organisasi apapun bidang kegiatannya. Hal yang paling rawan adalah apabila efesiensi selalu diartikan sebagi suatu penghematan, karena bisa mengangu operasi, sehingga pada giliranya akan mempengaruhi hasil akhir, karena sasarannya tidak tercapai dan produktivitasnya juga setinggiyang diharapkan.

Peran perusahaan agar personal selling bekerja dengan baik seperti keinginan perusahaan maka perusahaan harus merefleksikan keputusan mulai dari rekruitmen dan seleksi, pelatihan, penyeliaan, pemotivasian dan evaluasi kerja. Menurut Chandra (2002:210) yang digunakan untuk mengevaluasi bagaimana efektivitas kinerja personal selling pada peningkatan penjualan pada perusahaan adalah yang pertama penyediaan intelejensi pemasaran yaitu, kemampuan tenaga penjual untuk mendapatkan dan menyampaikan umpan balik informasi mengenai program pesaing, reaksi pelanggan, tren pasar dan faktor- faktor lainnya yang bermanfaat dalam penyususnan program promosi, yang kedua aktivitas tindak lanjut (follow up activities) yaitu, penggunaan dan penyebarluasan brosur-brosur dan korespondensi promosional dengan para pelanggan baru dan pelanggan saat ini. Penyediaan umpan balik yakni mencakup efektivitas berbagai program promosi, yang ketiga implementasi program, jumlah program promosi yang diimplementasikan jumah rak dan konter pajangan yang digunakan, dan yang ke empat pencapaian tujuan komunikasi, jumlah pelanggan yang menjadi target penetrasi, jumlah tawaran product trial dan seterusnya.

Efektivitas adalah pengukuran keberhasilan dalam pencapaian tujuan yang telah ditentukan sebelumnya. Efektivitas menunjukkan keberhasilan dari segi tercapai tidaknya indikator yang telah ditetapkan yaitu tepat jumlah, waktu, sasaran, harga, administrasi dan kualitas. Jika kegiatan mendekati indikator berarti makin tinggi efektivitasnya. Untuk peningkatan efektivitas pemerintah menerapkan sistem manajemen yang baik, manajemen waktu dan pengelolaan. Menurut Sugiyono, (2013:238) dalam perhitungan persentase efektivitas, dikategorikan efektif apabila mencapai minimal satu persen dan maksimal seratus persen.

PT. Wisundha Network Globalindo Tabanan merupakan salah satu perusahaan internet sevice provider (ISP) terkenal di daerah Tabanan, Bali yang berlokasi di Jalan Mawar No.40 Delod Peken Tabanan, Bali. Strategi yang diterapkan oleh PT. Wisundha Network Globalindo Tabanan terdiri dari tiga strategi, yaitu online marketing, personal selling, dan direct selling. Dari berbagai strategi yang diterapkan, salah satu diantaranya yang dapat menjual produk lebih banyak ke pelanggan dengan memberikan diskon atau potongan harga sebesar $5 \%$, gratis pemasangan dan garansi dari pembelian produk adalah strategi personal selling. Menurut William G. Nickels, (dalam Hermawan 2012:107), Personal Selling adalah interaksi antar individu, saling bertemu muka yang ditujukan untuk menciptakan, memperbaiki, menguasai dan mempertahankan hubungan pertukaran yang saling menguntungkan dengan pihak lain.

PT. Wisundha Network Globalindo Tabanan mempunyai persaingan yang ketat dengan produk-produk sejenis. Pada kenyataannya melalui penerapan strategi personal selling telah terbukti dapat memenuhi kebutuhan mulai dari konsumen kelas bawah hingga konsumen kelas atas. Berdasarkan penerapan strategi personal 
selling pada PT. Wisundha Network Globalindo Tabanan, diperoleh rata-rata volume penjualan produk sebesar $\mathrm{Rp}$ 40.638.000,00 setiap bulannya. Penjualan tertinggi dicapai pada bulan November sebesar $\mathrm{Rp}$ 46.115.000,00. Sedangkan penjualan terendah dicapai pada bulan Februari sebesar Rp 34.775.000,00 (Dokumentasi Data Penjualan PT. Wisundha Network Globalindo Tabanan Tahun 2017). Dari data tersebut bahwa tinggi rendahnya jumlah penjualan berkaitan dengan permintaan produk yang ditentukan oleh preferensi konsumen.

Permasalahan yang muncul adalah banyaknya produk yang terjual dalam strategi personal selling hanya dapat dilakukan pada pelanggan yang sudah menggunakan produk tersebut dan bukan untuk menarik pengguna baru serta penjualan juga tidak dapat dilakukan setiap hari karena harus menunggu permintaan dari pelanggan. Sehingga keberhasilan usaha penjualan produk dalam startegi personal selling berdampak pada volume penjualan yang didapat. Volume penjualan adalah hasil yang dicapai oleh perusahaan atau instansi dari waktu ke waktu pada umumnya tetap, tetapi selalu naik turun. Berdasarkan uraian di atas, peneliti tertarik untuk melakukan penelitian Bagaimana efektivitas personal selling pada PT. Wisundha Network Globalindo Tabanan

\section{METODE}

Jenis penelitian ini adalah jenis penelitian deskriptif. Penelitian deskriptif adalah penelitian yang mengambarkan data dalam bentuk pemaparan. Dalam penelitian ini menghasilkan data mengenai bagaimana efektivitas personal selling pada PT. Wisundha Network Globalindo Tabanan. Dengan sumber data primer dan skunder serta melalui teknik pengumpulan data dengan cara observasi pada objek yang diteliti, wawancara kepada produsen dan konsumen dalam strategi komunikasi pemasaran dan dokumentasi yang berhubungan terhadap promosi personal selling tersebut. Selain itu, memperoleh data dari sumber lain seperti refrensi tertentu yang berhubungan dengan promosi personal selling merupakan salah satu sumber yang membantu memberikan data yang jelas agar dapat mendukung penelitian yang dilakukan. Semua itu dilakukan untuk mendapatkan hasil yang sempurna dalam sebuah penelitian.

PT. Wisuandha Network Globalindo Tabanan menyediakan Akses Internet di tempat umum seperti shopping mall, hotel, restaurant, cafe, foodcourt, universitas, dan sekolah, dimana pengguna bisa mengakses ke dunia internet cukup dengan menggunakan alat-alat milik sendiri seperti laptop, notebook, dan pda phone, dengan menggunakan WiFi (akses internet tanpa menggunakan kabel apapun). Hotspot Zone/Wifi Zone yang telah kami pasang sampai saat ini adalah Shopping Mall, Plaza, dan Hotel.

Lokasi penelitian ini dilakukan di Jalan Mawar No. 40 Delod Peken Tabanan Kota, Bali, Indonesia. Subjek dalam penelitian ini adalah karyawan yang memberikan informasi mengenai efektivitas personal selling pada PT. Wisundha Network Globalindo Tabanan, dan objek dalam penelitian ini adalah efektivitas personal selling pada PT. Wisundha Network Globalindo Tabanan.

Jenis data yang digunakan dalam penelitian ini adalah deskriptif. Dalam penelitian ini menghasilkan data mengenai bagaimana efektivitas personal selling pada PT. Wisundha Network Globalindo Tabanan. Sumber data primer dalam penelitian ini yaitu hasil wawancara dan hasil observasi di PT. Wisundha Network Globalindo Tabanan. Sumber data sekunder dalam penelitian ini yaitu data yang diperoleh dari buku-buku pedoman tentang promosi dan juga berbagai sumber yang terkait dengan penelitian efektivitas personal selling pada PT. Wisundha Network Globalindo Tabanan.

Metode pengumpulan data dan instrumen penelitian yang digunakan dalam penelitian ini adalah observasi, wawancara, dan dokumentasi. Observasi dalam pengumpulan data dan instrument penelitian yaitu teknik pengumpulan data dengan cara mengadakan pengamatan secara langsung. Dalam hal ini dilakukan penelitian mengenai efektivitas personal selling pada PT. Wisundha Network Globalindo Tabanan dan dalam hal ini observasi dapat dilakukan dengan cara tes, 
kuisoner, ragam gambar, dan rekaman suara. Wawancara dalam pengumpulan data dan instrument penelitian yaitu teknik pengumpulan data dengan cara melakukan wawancara dan tanya jawab langsung dengan responden yang berhubungan dengan penelitian. Wawancara dilakukan untuk menjaring data tentang efektivitas personal selling pada PT. Wisundha Network Globalindo Tabanan. Wawancara ditunjukan kepada karyawan perusahaan PT. Wisundha Network Globalindo Tabanan. Dokumentasi dalam pengumpulan data dan instrument penelitian yaitu Teknik pengumpulan data dengan cara mengumpulkan dokumen yang artinya tertulis, didalam melaksanakan metode dokumentasi. Penelitian menyelidiki benda-benda tertulis seperti buku-buku, brosur, dan sebagainya di perusahaan PT. Wisundha Network Globalindo.

Metode analisis data dalam penelitian ini adalah Menurut Sugiyono (2013:238), dalam perhitungan persentase efektivitas, dikategorikan efektif apabila mencapai minimal satu persen dan maksimal seratus persen. Untuk mengukur efektifitas di Personal Selling menggunakan rumus :

$$
E=\frac{\text { Realisasi Penjualan }}{\text { T'arget Penjualan }} \times 100 \%
$$

Selain itu skala dan klasifikasi pengukuran kinerja instansi pemerintah, sumber Depdagri, Permendagri, Tahun 2011 dapat dilihat dalam Tabel 1 sebagai berikut.

Tabel 1. Skala dan Klasifikasi Pengukuran Efektivitas Kinerja Instansi Pemerintah

\begin{tabular}{cc}
\hline Pengukuran Ketepatan (\%) & Kriteria Keefektivan \\
\hline$\leq 20 \%$ & Sangat Tidak Efektif \\
$21 \%-40 \%$ & Tidak Efektif \\
$41 \%-60 \%$ & Cukup Efektif \\
$61 \%-80 \%$ & Efektif \\
$81 \%-100 \%$ & Sangat Efektif \\
\hline
\end{tabular}

Sumber: Depdagri, Permendagri, Tahun 2011

\section{HASIL DAN PEMBAHASAN \\ Hasil Penelitian Efektivitas Personal Selling}

Berdasarkan data yang berhasil dihimpun pada PT. Wisundha Network Globalindo
Tabanan belum dapat mencapai target yang telah ditetapkan, namun demikian penjualan sudah sangat efektif. $\mathrm{Hal}$ ini dapat dilihat dari hasil perhitungan efektivitas, berikut.

$$
\left.\frac{\text { Rp. } 487.656 .00,00}{\text { Rp. } 600.000 .000,00} \times 100 \%=\text { hasil } 81,2 \% \text { (Sangat Efektif }\right)
$$

Apabila dianalisis atau dihitung efektivitas personal selling perbulan selama satu tahun, menunjukan pada bulan Januari, Februari, Maret, April, dan Mei penjualan sudah efektif dan pada bulan Juni, Juli, Agustus, September, Oktober, November, dan Desember penjualan sangat efektif.. Hal ini dapat dilihat pada tabel 2 berik 
Tabel 2. Penjualan Produk Menggunakan Strategi Personal Selling

Dengan Skala dan Klasifikasi Pengukuran Efektivitas Kinerja PT. Wisundha Network Globalindo Tabanan Tahun 2017

\section{Efektivias}

\begin{tabular}{|c|c|c|c|c|c|c|c|c|c|}
\hline No & Bulan & Target Penjualan & Realisasi & $\%$ & $\begin{array}{c}\text { Sangat } \\
\text { Tidak } \\
\text { Efektif }\end{array}$ & $\begin{array}{c}\text { Tidak } \\
\text { Efektif }\end{array}$ & $\begin{array}{l}\text { Cukup } \\
\text { Efektif }\end{array}$ & Efektif & $\begin{array}{l}\text { Sangat } \\
\text { Efektif }\end{array}$ \\
\hline 1 & Januari & Rp. 50.000.000,00 & Rp. 35.025.000,00 & $70 \%$ & & & & $\square$ & \\
\hline 2 & Februari & Rp. $50.000 .000,00$ & Rp. $34.775 .000,00$ & $69.5 \%$ & & & & $\square$ & \\
\hline 3 & Maret & Rp. $50.000 .000,00$ & Rp. 34.925.000,00 & $69.8 \%$ & & & & $\square$ & \\
\hline 4 & April & Rp. $50.000 .000,00$ & Rp. 35.275.000,00 & $70.5 \%$ & & & & $\square$ & \\
\hline 5 & Mei & Rp. $50.000 .000,00$ & Rp. $39.491 .000,00$ & $78.9 \&$ & & & & $\square$ & \\
\hline 6 & Juni & Rp. 50.000.000,00 & Rp. 42.175.000,00 & $84.3 \%$ & & & & & $\square$ \\
\hline 7 & Juli & Rp. 50.000.000,00 & Rp. 43.225.000,00 & $86.4 \%$ & & & & & $\square$ \\
\hline 8 & Agustus & Rp. 50.000.000,00 & Rp. 42.325.000,00 & $84.6 \%$ & & & & & $\square$ \\
\hline 9 & September & Rp. 50.000.000,00 & Rp. 44.575.000,00 & $89.1 \%$ & & & & & $\square$ \\
\hline 10 & Oktober & Rp. 50.000.000,00 & Rp. 45.925.000,00 & $91.8 \%$ & & & & & $\square$ \\
\hline 11 & November & Rp. $50.000 .000,00$ & Rp. 46.115.000,00 & $92.2 \%$ & & & & & $\square$ \\
\hline \multirow[t]{2}{*}{12} & Desember & Rp. $50.000 .000,00$ & Rp. 43.825.000,00 & $87.6 \%$ & & & & & $\square$ \\
\hline & Total & Rp. $600.000 .000,00$ & Rp. $487.656 .000,00$ & $81.2 \%$ & & & - & 5 & 7 \\
\hline
\end{tabular}

Sumber: Dokumentasi Penjualan PT. Wisundha Network Globalindo Tabanan Tahun 2017

\section{Pembahasa}

Berdasarkan hasil penelitian menunjukan bahwa bulan januari - bulan mei personal selling efektif di pergunakan di PT. Wisundha Network Globalindo Tabanan untuk meningkatkan penjualan, dan pada bulan juni - bulan desember menunjukan peningkatan efektivitas penjualan dengan hasil sangat efektif di pergunakan di PT. Wisundha Network Globalindo Tabanan untuk meningkatkan penjualan yang dalam hal ini sesuai dengan teori Sugiyono (2013:238), dalam perhitungan persentase efektivitas, dikategorikan efektiv apabila mencapai minimal satu persen dan maksimal seratus persen pada personal selling. Hal ini juga didukung oleh penelitian terdahulu.

Penelitian Zuhdi Bahtiar Satoto (2011), yang berjudul "Efektivitas Personal Selling Di CV. Multindo Prima Sejahtera Wonogiri". Penelitian ini bertujuan untuk mengetahui efektivitas personal selling di CV. Multindo Prima Sejatera Wonogiri. Hasil analisi data yang dilakukan diketahui tingkat keberhasilan personal selling dalam memenuhi target penjualan perusahaan adalah $105 \%$ hingga $150 \%$ dikategorikan bahwa kinerja personal selling dalam menjual produk selama 6 bulan pada tahun 2010 sangat efektif karena melebihi target yang ditetapkan. Selain itu jika dilihat dari waktu kerja personal selling yang hanya berjalan \pm 6 bulan atau setengah tahun saja maka pencapaian penjualan tenaga personal selling dikatakan sangat efesien. Penelitian Puput Hayatun Nufus (2014), yang berjudul "Efektivitas komunikasi Pemasaran (Point Pertahun) Dalam Meningkatkan Minat Beli Pelanggan PT. Nusantara Sidhayatra Di Wilayah Banten - Tanggerang Periode 2013". Penelitian ini bertujuan untuk mengetahui efektivitas komunikasi pemasaran (point pertahun) dalam meningkatkan minat beli pelanggan PT. Nusantara Sidhayatra periode 2013. Hasil penelitian menunjukan bahwa komunikasi pemasaran (point pertahun) efektif, dalam meningkatkan minat beli pelanggan PT. Nusantara Sidhayatra dengan presentase sebesar $82,2 \%$. Penggunaan program (point pertahun) menjadi daya tarik sendiri terhadap penjulan oli federal di PT. 
p-ISSN : 2599-1418

e-ISSN : 2599-1426

Nusantara Sidhayatra.

\section{Penutup \\ Simpulan}

Berdasarkan hasil penelitian dan pembahasan pada bab sebelumnya, maka dapat disimpulkan adalah PT. Wisundha Network Globalindo Tabanan belum dapat mencapai target yang telah ditetapkan. Total reralisasi penjualan PT. Wisundha Network Globalindo Tabanan pada tahun 2017 sebesar $\mathrm{Rp}$ 487.656.000,00 dan target penjualan pada tahun 2017 sebesar Rp 600.000.000,00. Dalam hal ini penjualan PT. Wisundha Network Globalindo Tabanan pada tahun 2017 tidak memenuhi target penjualan, namun demikian dari hasil perhitungan efektivitas $81,2 \%$ sangat efektif.

\section{Saran}

Berdasarkan simpulan yang dipaparkan di atas, maka dapat diungkapkan beberapa saran terkait dengan hasil penelitian ini adalah PT. Wisundha Network Globalindo diharapkan mempertahankan efektivitas personal selling dengan terus melakukan pengembangan dan meningkatkan strategi pemasaran yang diterapkan dan PT. Wisundha Network Globalindo lebih mengutamakan dalam mempertahankan loyalitas pelanggan, ini bertujuan agar penjualan semakin tinggi.

\section{Daftar Pustaka}

Abdul, W. 2016. Revolusi Manajemen Pemasaran. Jakarta : Mitra Wacana Media

Alma, B. 2012. Manajemen Pemasaran Dan Pemasaran Jasa. Bandung : Alfabeta

Assuari, S. 2013. Manajemen Pemasaran. Jakarta : Rajawali Pers

Chandra, G. 2002. Strategi dan Program Pemasaran. Yogyakarta: Andi Offset

Gitosudarmo, Indriyo. 2000. Manajemen Pemasaran. Yogyakarta : BPFE Yogyakarta

Hasan. 2008. Marketing. Yogyakarta :
Jurnal Pendidikan Ekonomi

Volume 9 No.2 Tahun: 2017

Media Utama

Hermawan, A. 2012. Komunikasi Pemasaran. Jakarta: Erlangga.

Kotler \& Amstrong. 2012. Prinsip-Prinsip Pemasaran. Edisi 13. Jilid 1. Jakarta : Erlangga

Narbuko, A. 2009. Metodelogi Penelitian. Jakarta : Bumi Aksara

Nufus, P.H. (2014). Efektivitas komunikasi Pemasaran "Point Pertahun" Dalam Meningkatkan Minat Beli Pelanggan PT. Nusantara Sidhayatra Di Wilayah Banten - Tanggerang Periode 2013. Banten : Universitas Sultan Ageng Tirtayasa

Pasalong, H. 2012. Teori Administrasi Publik. Bandung : Alfabeta

Siagian, S.P. 2002. Kepemimpinan Organisasi Dan Perilaku Administrasi. Jakarta : Gunung Agung

Sugiyono. 2013. Metode Penelitian Kuantitatif, Kualitatif Dan $R \& D$. Bandung : CV. Alfabeta

Satoto, Z.B. (2011). Efektivitas Personal Selling Di CV. Multindo Prima Sejahtera Wonogiri. Surakarta : Universitas Sebelas Maret

Swastha, B. 2000. Manajemen Pemasaran Modern. Jakarta : PT. Raja Grafindo Persada

2005. Asas Asas Marketing.

Yogyakarta : Liberty ,. 2008. Manajemen Pemasaran Modern. Yogyakarta: Liberty 